\title{
Chronic hyperglycaemia promotes lipogenesis and triacylglycerol accumulation in human skeletal muscle cells
}

\author{
V. Aas ${ }^{1}$ E. T. Kase ${ }^{1}$ R. Rolberg ${ }^{1}$ J. Jensen ${ }^{2}$ A. C. Rustan ${ }^{1}$ \\ ${ }^{1}$ Department of Pharmacology, School of Pharmacy, University of Oslo, Oslo, Norway \\ ${ }^{2}$ National Institute of Occupational Health, Oslo, Norway
}

\begin{abstract}
Aims/hypothesis. The present study was conducted to evaluate the effect of hyperglycaemia in itself on glucose and lipid metabolism in human skeletal muscle cells.

Methods. Satellite cells were isolated from biopsy samples from the vastus lateralis muscle and differentiated into multinucleated myotubes in cultures. Metabolism studies were performed using isotopes $\left(\left[{ }^{3} \mathrm{H}\right]\right.$ deoxyglucose, $\left[{ }^{14} \mathrm{C}\right]$ glucose, $\left[{ }^{14} \mathrm{C}\right]$ oleic acid and $\left[{ }^{14} \mathrm{C}\right]$ palmitic acid), and mRNA and protein levels were analysed by real-time RT-PCR and western blotting respectively.

Results. Exposure of myotubes to $20 \mathrm{mmol} / \mathrm{l}$ glucose for 4 days reduced insulin-stimulated glucose uptake and glycogen synthesis to $57 \pm 5 \% \quad(p<0.0001)$ and $56 \pm 5 \%(p<0.0001)$ of normoglycaemic $(5.5 \mathrm{mmol} / \mathrm{l}$ glucose) controls respectively. Basal glucose uptake and glycogen synthesis were both reduced, whereas glucose oxidation was unaltered. Total cell content of glycogen and expression of GLUT1 and GLUT4 mRNA were not affected. There was a significant increase in the incorporation of glucose into cellular NEFA $(88 \pm 17 \%$ increase, $p=0.006)$, triacylglycerol $(44 \pm 21 \%$ increase, $p=0.04)$ and cholesterol ester
\end{abstract}

$(89 \pm 36 \%$ increase, $p=0.02)$ in hyperglycaemic myotubes compared with controls. Diacylglycerol tended to be increased though not significantly, and phospholipid formation were unchanged. Relative to controls, total cell content of triacylglycerol was increased by $25 \pm 7 \%(p=0.02)$ and acyl-CoA:1,2-diacylglycerol acyltransferase 1 activity was increased by $34 \pm 4 \%$ $(p=0.004)$, whereas acyl-CoA:1,2-diacylglycerol acyltransferase $1 \mathrm{mRNA}$ expression was unchanged. Total cellular uptake of palmitic acid was reduced by $18 \pm 3 \%(p=0.006)$ in hyperglycaemic cells compared with controls, while uptake of oleic acid was unchanged. Oxidation of palmitic acid or oleic acid was not affected by hyperglycaemia.

Conclusions/interpretation. Chronic hyperglycaemia increased triacylglycerol accumulation and the incorporation of carbohydrate into triacylglycerol (i.e. de novo lipogenesis) concomitantly with a reduced insulin-stimulated glucose uptake and glycogen synthesis. Enhanced acyl-CoA:1,2-diacylglycerol acyltransferase 1 activity supported the increased triacylglycerol synthesis during hyperglycaemia.

Keywords Glucose metabolism · GLUT · Human myotubes · Hyperglycaemia · Lipid metabolism · Lipogenesis · Protein kinase B
Received: 5 January 2004 / Accepted: 19 April 2004

Published online: 28 July 2004

(C) Springer-Verlag 2004

\section{Aas $(\bowtie)$}

Department of Pharmacology, School of Pharmacy,

University of Oslo, P.O. Box 1068, Blindern,

0316 Oslo, Norway

E-mail: vigdisaa@farmasi.uio.no

Tel.: +47-22856561, Fax: +47-22854402

Abbreviations: ASM, acid-soluble metabolites · CE, cholesterol ester - CPT-1, carnitine palmitoyltransferase 1 . DGAT-1, acyl-CoA:1,2-diacylglycerol acyltransferase 1 . $\alpha$ MEM, minimum essential medium $\alpha$ medium $\cdot$ PKB, protein kinase B · PKC, protein kinase C $\cdot$ PL, phospholipids · TAG, triacylglycerol

\section{Introduction}

Hyperglycaemia significantly contributes to insulin resistance in skeletal muscle [1, 2, 3, 4]. The mechanism of this glucose toxicity in muscle is probably complex. One possible effect of glucose oversupply can be an increased muscular glycogen content. The glycogen concentration of skeletal muscle has been shown to be inversely correlated with both basal and insulinstimulated glucose uptake [5]. It is possible that impaired insulin-stimulated glucose uptake can be attributed to a reduction in the number of GLUT4 glucose transporters in the plasma membrane [6]. Insulin normally stimulates GLUT4 translocation through a 
mechanism dependent on phosphoinositide 3-kinase activity, which may also involve the downstream targets protein kinase $\mathrm{B}(\mathrm{PKB})$ and atypical protein kinase C (PKC) [7, 8]. Derave et al. [9] demonstrated that muscle glycogen content affects insulin-stimulated GLUT4 translocation and PKB activity in fasttwitch muscles. If hyperglycaemia increases muscular glycogen content, this could provide a feasible explanation for the observed reduction in insulin-stimulated glucose uptake. Expression of the glucose transporters GLUT1 and GLUT4 may also be affected by hyperglycaemia $[10,11]$.

Glucose oversupply has also been associated with an increase in muscle triacylglycerol (TAG) and malonyl-CoA $[12,13]$. Muscular TAG content is strongly related to insulin resistance [14], and malonyl-CoA is known to inhibit carnitine palmitoyltransferase 1 (CPT-1), which is responsible for the transport of longchain acyl-CoA into the mitochondria $[15,16]$. Laybutt et al. [13] reported increased intramuscular levels of both long-chain acyl-CoA and malonyl-CoA after chronic glucose infusion in rats. These changes correlated with the chronic activation of PKC- $\varepsilon$. Precisely how glucose oversupply leads to lipid accumulation, and how this is linked to PKC activation, remains to be established. De novo lipogenesis is not assumed to take place in human skeletal muscles to a significant extent. However, even if glucose is not involved in lipid accumulation, it has been reported to have a negative effect on insulin signalling mediated by PKC isoforms in several cell systems [17, 18, 19, 20].

The present study aimed to examine the effects of hyperglycaemia in itself on skeletal muscle. The effects of glucose oversupply can be difficult to study in vivo, where it most often appears in conjunction with hyperinsulinaemia and disturbances in lipid metabolism. Consequently, we opted to study glucose and lipid metabolism in human skeletal muscle cells in vitro after exposure to chronic high glucose concentrations.

\section{Materials and methods}

Materials. The skeletal muscle cell growth medium Bullet kit was obtained from Clonetics (BioWhittaker, Verviers, Belgium). Ham's F-10 medium, trypsin/EDTA, FCS, penicillin/streptomycin $(10,000 \mathrm{IE} / 10,000 \mu \mathrm{g} / \mathrm{ml})$, fungizone, L-glutamine and minimum essential medium $\alpha$ medium ( $\alpha$ MEM) were from Gibco BRL (Paisley, UK). Extracellular matrix gel, cytochalasin B, BSA (essentially fatty acid free), L-carnitine, 2-deoxy-D-glucose and glycogen (rabbit liver) were from Sigma-Aldrich (St. Louis, Mo., USA). We obtained 2-[ $\left.{ }^{3} \mathrm{H}(\mathrm{G})\right] \mathrm{de}-$ oxy-D-glucose $(370 \mathrm{GBq} / \mathrm{mmol}), \quad \mathrm{D}-\left[{ }^{14} \mathrm{C}(\mathrm{U})\right]$ glucose $(448$ $\mathrm{MBq} / \mathrm{mmol}), \mathrm{D}-\left[1-{ }^{14} \mathrm{C}\right] \mathrm{glucose}(2.04 \mathrm{GBq} / \mathrm{mmol}),\left[1-{ }^{14} \mathrm{C}\right]$ oleic acid $(1.96 \mathrm{GBq} / \mathrm{mmol})$ and $\left[1-{ }^{14} \mathrm{C}\right]$ palmitic acid $(2.0 \mathrm{GBq} /$ mmol) from Du Pont NEN Life Sciences Products (Boston, Mass., USA). Insulin Actrapid was from Novo Nordisk (Bagsvaerd, Denmark). Amyloglucosidase and glucose-6phosphate dehydrogenase were from Boehringer Ingelheim (Ingelheim am Rhein, Germany). Thin-layer chromatography plates (Silica gel) were from Merck (Darmstadt, Germany). The scintillation liquids Instagel and Hionic were from Packard Bioscience (Groningen, The Netherlands).

Human skeletal muscle cell cultures. A cell bank of satellite cells was established from muscle biopsy samples of the vastus lateralis muscle from four healthy volunteers (age 24.8 \pm 1.1 years, BMI 22.2 \pm 1.5 , fasting glucose and insulin within the normal range and no family history of diabetes). The biopsies were obtained with informed consent and approval by the $\mathrm{Na}$ tional Committee for Research Ethics, Oslo, Norway. Muscle cell cultures free of fibroblasts were established as previously described [21] with minor modifications. Briefly, muscle tissue was dissected in Ham's F-10 media at $4{ }^{\circ} \mathrm{C}$, dissociated by three successive treatments with $0.05 \%$ trypsin/EDTA, and then satellite cells were resuspended in skeletal cell growth medium with $2 \%$ FCS and no added insulin. The cells were grown on culture wells coated with extracellular matrix gel [22]. After 2 to 3 weeks at about $80 \%$ confluence, fusion of myoblasts into multinucleated myotubes was achieved by growth for 8 days in $\alpha$ MEM with $2 \%$ FCS. Hyperglycaemic medium was made by the addition of glucose (to a concentration of 10 or $20 \mathrm{mmol} / \mathrm{l}$ ) to $\alpha \mathrm{MEM}$ with $2 \%$ FCS. All cells used in the experiments were at passage 3 to 6 .

Deoxyglucose uptake. Myotubes were incubated for $60 \mathrm{~min}$ $\left(37{ }^{\circ} \mathrm{C}, 5 \% \mathrm{CO}_{2}\right)$ in serum-free $\alpha \mathrm{MEM}$ containing $5.5 \mathrm{mmol} / \mathrm{l}$ glucose $\left( \pm\right.$ insulin), before adding $2-\left[{ }^{3} \mathrm{H}(\mathrm{G})\right]$ deoxy-D-glucose (3.7 and $37 \mathrm{kBq} / \mathrm{ml}$ ) and insulin (1-100 $\mathrm{nmol} / \mathrm{l})$. Deoxyglucose uptake was measured after incubation in medium containing $5.5 \mathrm{mmol} / \mathrm{l}$ glucose for $60 \mathrm{~min}$ or $10 \mu \mathrm{mol} / \mathrm{l}$ unlabelled deoxyglucose for $15 \mathrm{~min}$. After incubation, the cells were washed three times with ice-cold PBS, lysed with $0.05 \mathrm{~mol} / \mathrm{l} \mathrm{NaOH}$ and radioactivity was counted by liquid scintillation. Noncarrier-mediated uptake was determined in the presence of cytochalasin B $(5 \mu \mathrm{mol} / \mathrm{l})$ and subtracted from all presented values. The protein content of each sample was determined as described previously [23], and glucose uptake is presented as nmol glucose $\cdot \mathrm{mg}$ cell protein ${ }^{-1} \cdot \mathrm{min}^{-1}$. The effect of hyperglycaemia was not reversed by $1 \mathrm{~h}$ of incubation in $5.5 \mathrm{mmol} / \mathrm{l}$ glucose: glucose uptake was $105 \pm 3 \%$ that of cells pre-treated for $1 \mathrm{~h}$ in serum-free $20 \mathrm{nmol} / \mathrm{l}$ glucose. Insulin-stimulated glucose uptake was linear within $2 \mathrm{~h}$, and the effect of hyperglycaemia was not reversed by pre-treatment for $1 \mathrm{~h}$ in normoglycaemic $\alpha$ MEM (data not shown).

Glycogen synthesis. Myotubes were incubated for $60 \mathrm{~min}$ $\left(37{ }^{\circ} \mathrm{C}, 5 \% \mathrm{CO}_{2}\right.$ ) in serum-free $\alpha \mathrm{MEM}( \pm$ insulin), before adding $\mathrm{D}-\left[{ }^{14} \mathrm{C}(\mathrm{U})\right]$ glucose $(37$ and $74 \mathrm{kBq} / \mathrm{ml}, 5.5 \mathrm{mmol} / \mathrm{l})$ and insulin $(1-100 \mathrm{nmol} / \mathrm{l})$. After 60 to $120 \mathrm{~min}$, the cells were washed three times with ice-cold PBS and lysed with $1 \mathrm{~mol} / \mathrm{l}$ $\mathrm{KOH}$. Synthesised glycogen was measured as described [24]. Glycogen synthesis increased linearly within $4 \mathrm{~h}$ after insulin stimulation and is presented as nmol $\cdot \mathrm{mg}$ cell protein ${ }^{-1} \cdot \mathrm{h}^{-1}$.

Glucose oxidation. Myotubes were incubated with D-[1-14C] glucose $(18.5 \mathrm{KBq} / \mathrm{ml}, 5.5 \mathrm{mmol} / \mathrm{l}), 20 \mathrm{mmol} / \mathrm{l}$ HEPES with or without $100 \mathrm{nmol} / \mathrm{l}$ insulin in serum-free $\alpha \mathrm{MEM}$ in airtight $12.5 \mathrm{~cm}^{2}$ bottles with stopper tops. After $2 \mathrm{~h}, 300 \mu \mathrm{l}$ of phenyl ethylamine : methanol $(1: 1 \mathrm{v} / \mathrm{v})$ was added with a syringe to a centre well containing a folded filter paper. Subsequently, $300 \mu \mathrm{l}$ of $1 \mathrm{~mol} / \mathrm{l}$ perchloric acid was added to the cells through the stopper tops using a syringe. The flasks were placed for a minimum of $4 \mathrm{~h}$ at room temperature to trap labelled $\mathrm{CO}_{2}$. The filter paper was counted by liquid scintillation. Glucose oxidation is presented as $\mathrm{nmol} / \mathrm{mg}$ cell protein. No-cell controls were included to correct for non-specific $\mathrm{CO}_{2}$ trapping. 
Table 1. Characteristics of the PCR primers

\begin{tabular}{llr}
\hline Assay & Sequence & GenBank accession number \\
\hline$\beta$-actin & F: ACC GAG CGC GGC TAC A & NM_001101 \\
& R: TCC TTA ATG TCA CGC ACG ATT T & \multirow{2}{*}{ AF059202 } \\
DGAT-1 & F: TCC ACT CCT GCC TGA ATG C & \multirow{2}{*}{ K03195 } \\
GLUT1 & R: GGT GAC AGA CTC GGA GTT CCA & \\
GLUT4 & F: CAG CAG CCC TAA GGA TCT CTC A & M20747 \\
& R: CCG GCT CGG CTG ACA TC &
\end{tabular}

The accession number in the GenBank was used to design the primers in the Primer Express program. DGAT-1, acyl-CoA:1,2-diacylglycerol acyltransfease; F, forward primer; R, reverse primer

Glycogen content. Myotubes were dissolved in $1 \mathrm{~mol} / \mathrm{l} \mathrm{KOH}$, and the glycogen was hydrolysed to glucose with amyloglucosidase in acetate buffer as described previously [25]. Glucose units were measured fluorometrically by the method of Lowry and Passonneau [26].

Lipid distribution. Myotubes were incubated with either [1${ }^{14} \mathrm{C}$ ]oleic acid $(18.5 \mathrm{kBq} / \mathrm{ml}, 0.6 \mathrm{mmol} / \mathrm{l})$ or $\left[1-{ }^{14} \mathrm{C}\right]$ palmitic acid $(18.5 \mathrm{kBq} / \mathrm{ml}, 0.6 \mathrm{mmol} / \mathrm{l})$ plus or minus insulin $(100 \mathrm{nmol} / \mathrm{l})$ for $4 \mathrm{~h}$ before they were harvested into ice-cold PBS, centrifuged (1000 $g, 5 \mathrm{~min})$, resuspended in distilled water and sonicated. Cell-associated lipids were extracted with chloroform : methanol as described [27]. Briefly, $400 \mu \mathrm{l}$ of cell homogenate was mixed with $8 \mathrm{ml}$ of chloroform : methanol $(2: 1 \mathrm{v} / \mathrm{v})$, and FCS $(30 \mu \mathrm{l})$ was added as a carrier. After $30 \mathrm{~min}$, $1.6 \mathrm{ml}$ of $0.9 \% \mathrm{NaCl}(\mathrm{pH} 2)$ was added and the mixture was centrifuged (1000 $\mathrm{g}, 5 \mathrm{~min})$. The organic phase was evaporated under a steam of nitrogen at $40{ }^{\circ} \mathrm{C}$. The residual lipid extract was re-dissolved in $200 \mu \mathrm{l}$ of $n$-hexane and separated by thinlayer chromatography using hexane : diethylether : acetic acid (65:35:1) as the mobile phase. The bands were visualised with iodine, excised and counted by liquid scintillation. Lipids were also extracted after incubation of myotubes with $\mathrm{D}-\left[{ }^{14} \mathrm{C}(\mathrm{U})\right]$ glucose $(74$ and $111 \mathrm{kBq} / \mathrm{ml}, 5.5 \mathrm{mmol} / \mathrm{l}$ or $20 \mathrm{mmol} / \mathrm{l})$ for $24 \mathrm{~h}$.

Lipid oxidation. Cells were incubated in serum-free $\alpha \mathrm{MEM}$ with $0.5 \mathrm{mmol} / \mathrm{l} \mathrm{L}$-carnitine, $20 \mathrm{mmol} / \mathrm{l} \mathrm{HEPES,} \mathrm{[1-14C]oleic}$ acid $(18.5 \mathrm{kBq} / \mathrm{ml}, 0.6 \mathrm{mmol} / \mathrm{l})$ with or without $100 \mathrm{nmol} / \mathrm{l}$ of insulin, to study basal and insulin-mediated lipid oxidation. Flasks were made airtight using stopper tops. After 4 h, $300 \mu \mathrm{l}$ of phenyl ethylamine : methanol $(1: 1 \mathrm{v} / \mathrm{v})$ was added with a syringe to a centre well containing a folded filter paper. Subsequently, $300 \mu \mathrm{l}$ of $1 \mathrm{~mol} / \mathrm{l}$ perchloric acid was added to the cells through the stopper tops using a syringe. The flasks were placed for a minimum of $4 \mathrm{~h}$ at room temperature to trap labelled $\mathrm{CO}_{2}$. No-cell controls were included to correct for unspecific $\mathrm{CO}_{2}$ trapping. Radioactivity associated with the filter paper was counted by liquid scintillation.

To measure acid-soluble metabolites (ASM; fatty acid $\beta$ oxidation products), the cells were transferred to plastic tubes, and the flasks were rinsed with $1.5 \mathrm{ml}$ of perchloric acid $(1 \mathrm{~mol} / \mathrm{l})$ that was subsequently added to the same plastic tube. The tubes were then centrifuged for $10 \mathrm{~min}(1800 \mathrm{~g})$ and $1.0 \mathrm{ml}$ of the supernatant was counted by liquid scintillation. ASM were also measured in the growth media of cells grown on six-well plates that had been incubated with $\left[1-{ }^{14} \mathrm{C}\right]$ oleic acid and $\left[1-{ }^{14} \mathrm{C}\right]$ palmitic acid. A $250-\mu \mathrm{l}$ aliquot of the cell medium was precipitated with $100 \mu \mathrm{l}$ of $6 \%$ BSA and $1.0 \mathrm{ml}$ of $1 \mathrm{~mol} / \mathrm{l}$ perchloric acid. After centrifugation $(1800 \mathrm{~g}), 500 \mu \mathrm{l}$ of the supernatant was counted by liquid scintillation. No-cell controls were included.

Triacylglycerol content. Mass measurement of cellular TAG was performed using an enzymatic kit (Triglyceride GPOTrinder, Sigma-Aldrich) after extraction of the cell samples according to Folch et al. [27] and redissolved in $50 \mu \mathrm{l}$ of 2-propanol.

Assay of acyl-CoA:1,2-diacylglycerol acyltransferase 1. AcylCoA:1,2-diacylglycerol acyltransferase 1 (DGAT-1) activity was measured as previously described [28]. Briefly, homogenised cells ( $1 \mathrm{mg} / \mathrm{ml}$ in $175 \mathrm{mmol} / \mathrm{l}$ TRIS, $\mathrm{pH} 7.8)$ were mixed with 1,2-di[1-14 C]oleoylglycerol $(3.4 \mathrm{kBq} / \mathrm{ml}, 115$ $\mu \mathrm{mol} / \mathrm{l}), 20 \mu \mathrm{mol} / \mathrm{l}$ oleoyl-CoA, $1 \mathrm{mg} / \mathrm{ml}$ BSA, $8 \mathrm{mmol} / \mathrm{l}$ $\mathrm{MgCl}_{2}$ and incubated at room temperature for $10 \mathrm{~min}$ before the reaction was stopped by the addition of 20 volumes of chloroform : methanol $(2: 1 \mathrm{v} / \mathrm{v})$. The lipids were extracted and separated by thin-layer chromatography as explained above [27]. The TAG band was cut out and counted by liquid scintillation.

RNA isolation and analysis of gene expression by real-time $P C R$. Human skeletal muscle cells were washed, trypsinised and pelleted before total RNA was isolated by RNeasy Mini kit (50) (Qiagen Sciences, Md., USA) according to the supplier's total RNA isolation protocol. RNA samples were incubated with RNase-free DNase (Qiagen Sciences) for a minimum of $15 \mathrm{~min}$, in an additional step during the RNA isolation procedure. Total RNA was reversely transcribed with oligo primers using a Perkin-Elmer Thermal Cycler 9600 (Boston, Mass., USA; $25^{\circ} \mathrm{C}$ for $10 \mathrm{~min}, 37^{\circ} \mathrm{C}$ for $1 \mathrm{~h}, 99^{\circ} \mathrm{C}$ for $5 \mathrm{~min}$ ) and a TaqMan reverse-transcription reagents kit (Applied Biosystems, Warrington, UK). A 1- $\mu$ g aliquot of total RNA was added per $\mathrm{ml}$ of total TaqMan reaction solution. Real-time PCR was performed using an ABI PRISM 7000 Detection System (Applied Biosystems). DNA expression was determined by SYBR Green, and primers were designed using Primer Express (Applied Biosystems) (Table 1). Each target was quantified in triplicate and carried out in a $25-\mu$ reaction volume according to the supplier's protocol. All assays were run for 40 cycles $\left(95{ }^{\circ} \mathrm{C}\right.$ for $12 \mathrm{~s}$ followed by $60{ }^{\circ} \mathrm{C}$ for $\left.60 \mathrm{~s}\right)$. The transcription levels were normalised to the housekeeping control gene $\beta$-actin.

Immunoblotting. Aliquots containing $20 \mu \mathrm{g}$ of cell protein (total cell lysate prepared in Laemmli buffer) were separated by SDS-PAGE (using a $10 \%$ resolving gel) and transferred to polyvinylidene difluoride membranes. The membranes were immunoblotted with a phospho-Akt antibody (Ser473, Cell 
a

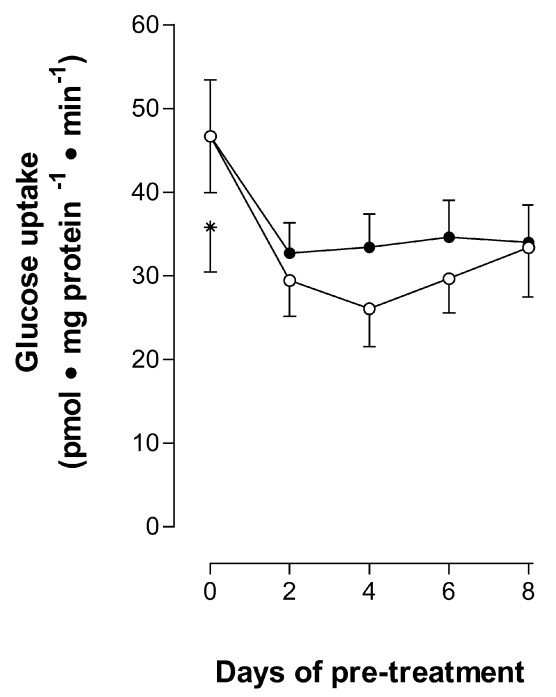

Fig. 1. Relationship between duration of hyperglycaemia and insulin-stimulated glucose uptake (a) and glycogen synthesis (b) in myotubes. At about $80 \%$ confluence, differentiation of myoblasts was induced and the cells were incubated in the presence of either 10 (filled circles) or 20 (open circles) $\mathrm{mmol} / \mathrm{l}$ glucose for the indicated periods of time. Insulin-stimulated $(100 \mathrm{nmol} / \mathrm{l})$ glucose uptake and glycogen synthesis were measured on day 8 as described in Materials and methods. Values are means \pm SEM from three separate experiments with triplicate observations. * Non-stimulated glucose uptake and glycogen synthesis

Signaling Technology, Beverly, Mass., USA) and a rabbit polyclonal antibody raised against a recombinant protein corresponding to amino acids 230-290 within human GLUT4 (H-61, Santa Cruz Biotechnology, Santa Cruz, Calif., USA). Immunoreactive bands were visualised with enhanced chemiluminescence (Amersham Biosciences, Buckinghamshire, UK).

Lactate dehydrogenase. Human skeletal muscle cells were grown in 24-well plates, differentiated and treated as described above. Lactate dehydrogenase activity in the cells was measured by a cytotoxicity kit (Sigma-Aldrich) using a positive control of cells treated with $1 \%$ Triton X-100. Control cells were exposed to differentiation medium ( $\alpha$ MEM with $2 \%$ FCS).

Statistical methods. All data are presented as means \pm SEM. Statistical comparison between different treatments was performed by ANOVA and the Student's $t$ test. A $p$ value of less than 0.05 was considered significant. All experiments were performed with triplicate observations, and replicate experiments were performed on cells from different donors.

\section{Results}

Insulin responsiveness of human skeletal muscle cells. Differentiation of myoblasts into multinucleated myotubes was confirmed by light microscopy (data not shown). At day 8 of differentiation the cells expressed GLUT4, as assessed by western blotting (data not b

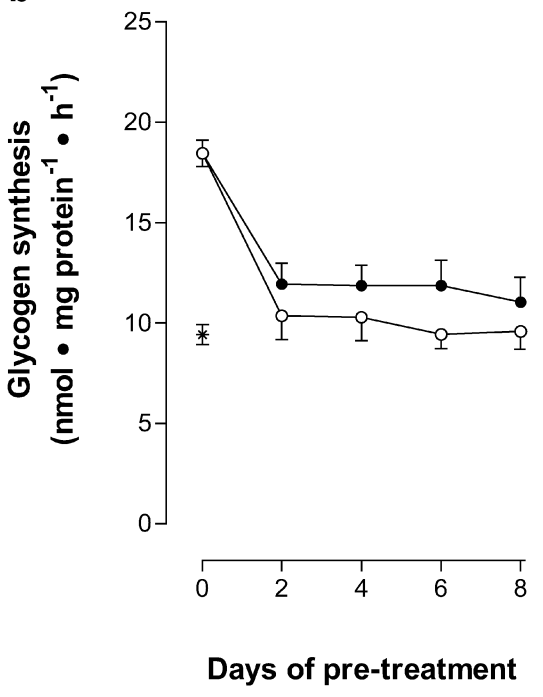

shown) and real-time RT-PCR. Basal glucose uptake was $124 \pm 18 \mathrm{nmol} \cdot \mathrm{mg}$ protein ${ }^{-1} \cdot \mathrm{h}^{-1}$ and basal glycogen synthesis was $12 \pm 2 \mathrm{nmol} \cdot \mathrm{mg}$ protein ${ }^{-1} \cdot \mathrm{h}^{-1}$. Insulin (100 nmol/l) increased glucose uptake by $56 \pm 11 \%$ above the basal level $(p=0.0003)$ and glycogen synthesis by $110 \pm 8 \%$ above the basal level $(p<0.0001)$.

Glucose metabolism after chronic hyperglycaemia. Hyperglycaemia (10 and $20 \mathrm{mmol} / \mathrm{l}$ glucose) reduced insulin-stimulated glucose uptake (Fig. 1a) and glycogen synthesis (Fig. 1b) in a time- and dose-dependent manner, with maximal reductions observed after 2 days of hyperglycaemia. After exposure to $10 \mathrm{mmol} / \mathrm{l}$ glucose for 4 days, insulin-stimulated glucose uptake was reduced to $75 \pm 3 \%$ of control values $(p=0.0001)$, while exposure to $20 \mathrm{mmol} / \mathrm{l}$ glucose for the same time period reduced insulin-stimulated glucose uptake to $57 \pm 5 \%$ of control levels $(p<0.0001)$. Glycogen synthesis at $10 \mathrm{mmol} / \mathrm{l}$ glucose and $20 \mathrm{mmol} / \mathrm{l}$ glucose was reduced to $64 \pm 4 \%(p<0.0001)$ and $56 \pm 5 \%(p<0.0001)$ of control values respectively. In muscle cells exposed to $20 \mathrm{mmol} / \mathrm{l}$ glucose for the last 4 days of the 8-day differentiation period, insulin stimulated both glucose uptake (Fig. 2a) and glycogen synthesis (Fig. 2b) in a dose-dependent manner. Total glucose utilisation by the cells was clearly reduced, although relative insulin responses were maintained (Fig. 2c). The same was true for insulin-stimulated glucose uptake (data not shown). In contrast, glucose oxidation assessed by $\mathrm{CO}_{2}$ trapping after incubation of myotubes with $\left[{ }^{14} \mathrm{C}\right] \mathrm{glu}-$ cose was not affected by 4 days of hyperglycaemia. Baseline glucose oxidation was $3.1 \pm 0.2 \mathrm{nmol} \cdot \mathrm{mg}$ protein $^{-1} \cdot \mathrm{h}^{-1}$ in control cells and $3.7 \pm 0.5 \mathrm{nmol} \cdot \mathrm{mg}$ protein ${ }^{-1} \cdot \mathrm{h}^{-1}$ in hyperglycaemic cells $(n=10)$.

The effect of hyperglycaemia on glycogen synthesis was reversible (Fig. 3). In cells grown in hyperglycaemic medium ( $20 \mathrm{mmol} / \mathrm{l}$ glucose $)$ for the first 4 days of the differentiation period, glycogen synthesis was reduced to $63 \%$ of control levels. Changing the hyperglycaemic medium to a normoglycaemic medi- 
a

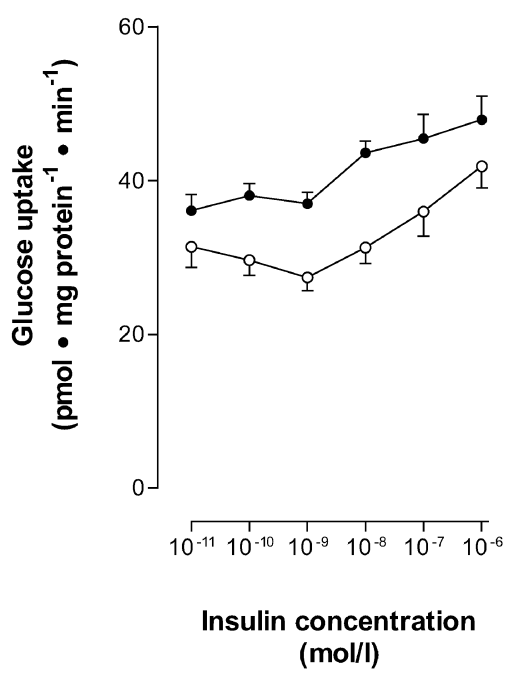

Fig. 2. Relationship between insulin concentration and (a) glucose uptake and (b), (c) glycogen synthesis in normoglycaemic (5.5 mmol/l glucose, filled circles) and hyperglycaemic (20 mmol/l glucose, open circles) myotubes. Human skeletal muscle cells were incubated with $\alpha$ MEM containing $2 \%$ FCS and the requisite glucose concentration for 4 days during differentiation before measurements were made. The cell medium was changed to serum-free $\alpha \mathrm{MEM}$ containing $5.5 \mathrm{mmol} / \mathrm{l} \mathrm{glu}-$ cose for $1 \mathrm{~h}$ prior to the measurements, and the cells were stimulated with insulin. Values are means \pm SEM from six (a) and four (b), (c) independent experiments with triplicate observations respectively. Calculations are based on data in (b)

um $(5.5 \mathrm{mmol} / \mathrm{l}$ glucose $)$ for the final 4 days of differentiation reversed the effect of hyperglycaemia, increasing glycogen synthesis to $116 \%$ of that in controls. Cell behaviour was apparently not affected by this treatment, and glycogen synthesis on day 4 did not differ from glycogen synthesis on day 8 in control cells. A toxic effect of hyperglycaemia was excluded as there was no detectable lactate dehydrogenase activity in the cell growth media after hyperglycaemia, and both hyperglycaemic and control cells had similar cell protein concentrations (data not shown).

Total cell glycogen, glucose transporters and protein kinase $B$ activity. The total cell content of glycogen was not changed after 4 days in hyperglycaemia medium $(20 \mathrm{mmol} / \mathrm{l}$ glucose $)$. The cell content of glycogen was $396 \pm 92 \mathrm{nmol} / \mathrm{mg}$ cell protein in hyperglycaemic cells compared with $358 \pm 65 \mathrm{nmol} / \mathrm{mg}$ cell protein in controls $(n=13, p=0.95)$. However, in cells treated with $20 \mathrm{mmol} / \mathrm{l}$ glucose plus $100 \mathrm{nmol} / \mathrm{l}$ insulin, glycogen content was significantly increased by $55 \pm 6 \%$ $(n=6, p=0.0002)$ after 4 days compared with controls, indicating an insulin-dependent effect (Fig. 4).

Expression of GLUT1 and GLUT4 mRNAs, as measured by real-time RT-PCR, was not regulated by hyperglycaemia (Fig. 5). GLUT4 mRNA expression seemed to be slightly reduced, but not significantly.
C

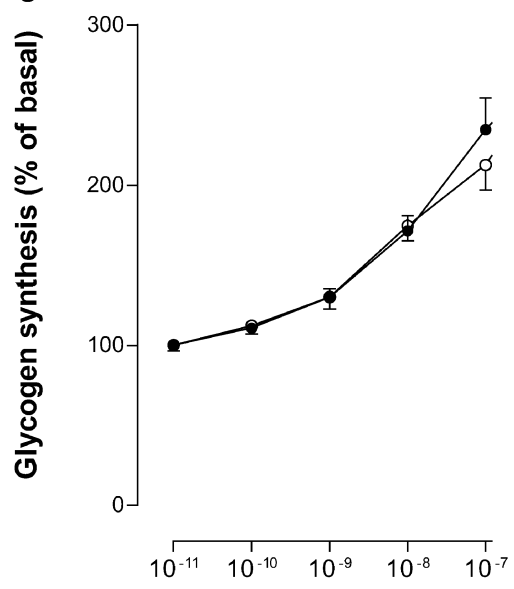

Insulin concentration (mol/l)

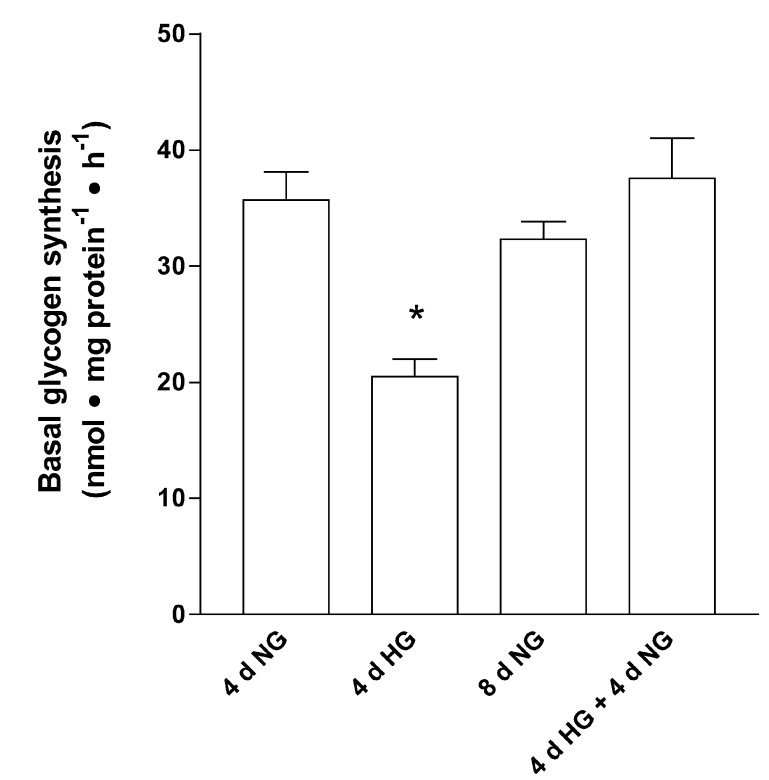

Fig. 3. Bar graph to show the reversible effect of hyperglycaemia on glycogen synthesis. Basal glycogen synthesis was assessed in human skeletal muscle cells treated with $20 \mathrm{mmol} / \mathrm{l}$ glucose for 4 days ( $4 \mathrm{~d} \mathrm{HG}$ ) followed by another 4 days with normoglycaemic medium containing $5.5 \mathrm{mmol} / 1$ glucose $(4 \mathrm{~d}$ $\mathrm{HG}+4 \mathrm{~d} \mathrm{NG})$. Control measurements were made in cells treated with normoglycaemic medium for 4 days $(4 \mathrm{~d} \mathrm{NG})$ or 8 days $(8 \mathrm{~d}$ NG). Values are means \pm SEM. * Significantly lower than normoglycaemic cells $(p<0.05)$

Activation of PKB, both basal and insulin-stimulated, measured as protein phosphorylation at Ser473, was also unchanged after chronic exposure to high glucose concentrations (Fig. 6).

Metabolism of glucose to lipids. Cells were treated with [ $\left.{ }^{14} \mathrm{C}\right]$ glucose $(5.5 \mathrm{mmol} / \mathrm{l}$ or $20 \mathrm{mmol} / \mathrm{l})$ for $24 \mathrm{~h}$ to assess the effect of hyperglycaemia on cellular lipid formation. In hyperglycaemic cells, the conversion of labelled glucose into NEFA $(88 \pm 17 \%, p=0.006)$, TAG $(44 \pm 21 \%, p=0.04)$ and cholesterol ester (CE) $(89 \pm 36$, 


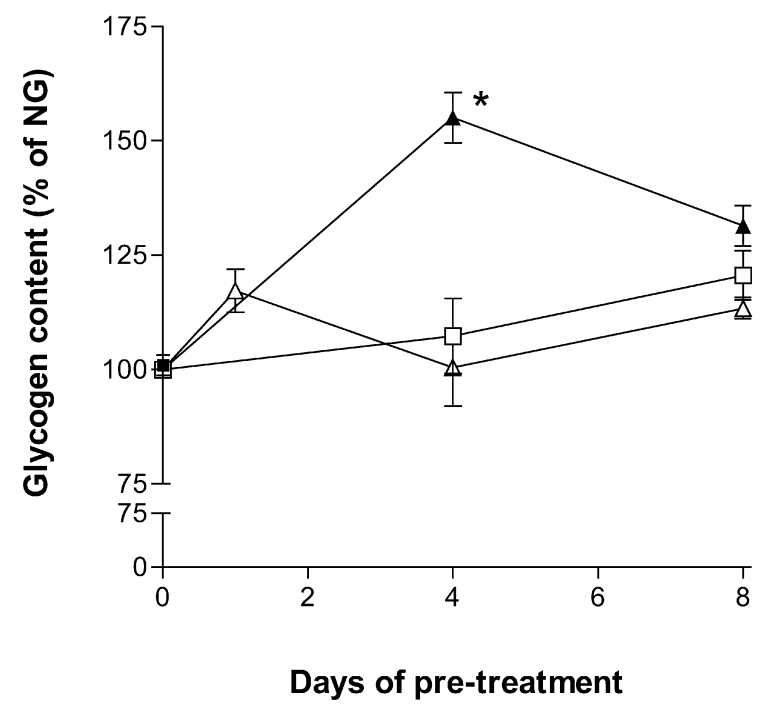

Fig. 4. Myotubular glycogen content. Myotubes were incubated with hyperglycaemic medium ( $\mathrm{HG}, 20 \mathrm{mmol} / \mathrm{l}$ glucose) or normoglycaemic medium ( $\mathrm{NG}, 5.5 \mathrm{mmol} / \mathrm{l}$ glucose) for 1 to 8 days prior to harvesting on the 8th day of differentiation. Results shown are for $\mathrm{HG}$ alone (open triangle), HG plus hyperinsulinaemia (100 nmol/l, closed triangle), NG alone (closed square) and NG plus hyperinsulinaemia (100 nmol/l, open square). Total cellular concentration of glycogen is given as percentage of $\mathrm{NG}$ control, i.e. cells that were grown in $5.5 \mathrm{mmol} / \mathrm{l}$ glucose for 8 days and contained $358 \pm 65 \mathrm{nmol}$ glycogen $/ \mathrm{mg}$ cell protein. Values are means \pm SEM of two to five experiments with triplicate observations. * Significantly increased above NG control $(p<0.02)$

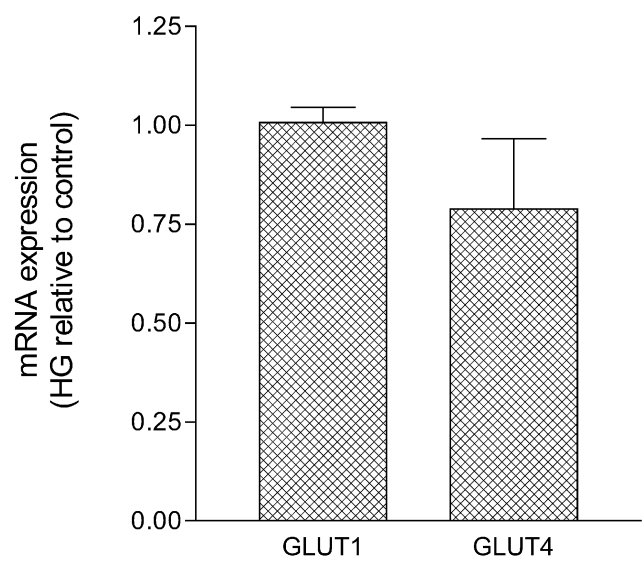

Fig. 5. Expression of GLUT1 and GLUT4 mRNAs after 4 days of hyperglycaemia (HG). Skeletal muscle cells were treated with $\mathrm{HG}$ medium ( $20 \mathrm{mmol} / \mathrm{l}$ glucose) from day 4 to 8 during differentiation. At day 8, cells were harvested and total mRNA was isolated by RNeasy Mini kit. Reverse-transcription and real-time PCR were performed. GLUT1 and GLUT4 were quantified relative to the housekeeping control $\beta$-actin. Values are ratios between $\mathrm{HG}$ and control cells from five separate experiments

$p=0.02)$ was significantly increased compared with controls (Fig. 7). Conversion into diacylglycerol also tended to be increased, although not significantly $(13 \pm 8 \%, p=0.2)$ (Fig. 7), and phospholipids (PL) were

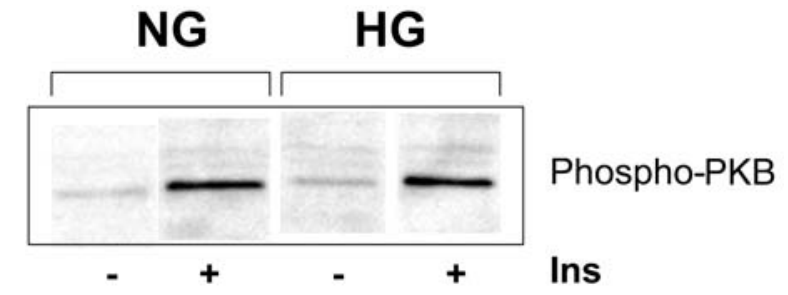

Fig. 6. Phosphorylation of protein kinase B. At day 8 of differentiation, normoglycaemic (NG) and hyperglycaemic (HG) cells were stimulated with or without insulin (Ins, $100 \mathrm{nmol} / \mathrm{l}$ ) for $20 \mathrm{~min}$ before harvesting into Laemmli buffer. SDS-PAGE with western blotting was then performed. Phosphorylated protein kinase $\mathrm{B}$ was detected using a monoclonal antibody directed against phosphorylated Ser473 (phospho-PKB). A representative blot from five separate experiments is shown

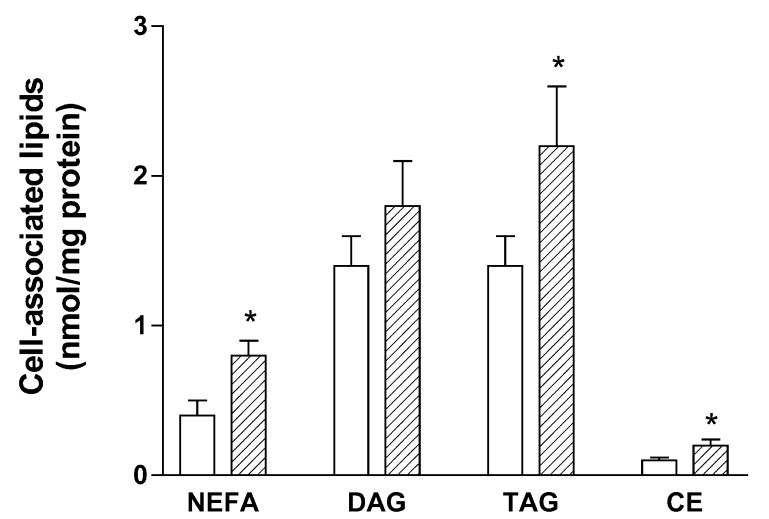

Fig. 7. Conversion of $\left[{ }^{14} \mathrm{C}\right]$ glucose to NEFA, diacylglycerol (DAG), triacylglycerol (TAG) and cholesterol ester (CE). $\left[{ }^{14} \mathrm{C}\right]$ glucose $(111 \mathrm{kBq} / \mathrm{ml}, 5.5 \mathrm{mmol} / \mathrm{l})$ was added to control cells (open bars) and hyperglycaemic cells (hatched bars) for the last $24 \mathrm{~h}$ of the differentiation period. Lipids were extracted from the cells, separated by thin-layer chromatography and quantified by liquid scintillation. Values are means \pm SEM of four separate experiments. *Significantly higher than normoglycaemic cells $(p<0.05)$

unaffected (data not shown). There was no significant difference between control and hyperglycaemic cells in the total amount of $\left[{ }^{14} \mathrm{C}\right]$ glucose-labelled cellular lipids $(30.5 \pm 4.1$ vs $34.1 \pm 4.7 \mathrm{nmol} / \mathrm{mg}$ protein respectively). The majority of the radioactivity was recovered in the PL fraction in both the control $(88 \pm 1 \%)$ and hyperglycaemic cells $(85 \pm 1 \%)$.

Total muscle cell content of TAG was significantly increased by $25 \pm 7 \%$ after 4 days of hyperglycaemia $(p=0.02$ ) (Fig. 8a). In line with this, DGAT-1 activity was also increased in hyperglycaemic cells. Conversion of 1,2-di[1-14C]oleoylglycerol into TAG was significantly increased by $34 \pm 4 \%$ in hyperglycaemic cells compared with controls $(p=0.004)$ (Fig. 8b). This elevated DGAT-1 activity was not due to increased expression of DGAT-1 mRNA (Fig. 8c).

Metabolism of oleic acid and palmitic acid after hyperglycaemia. Compared with normoglycaemic my- 


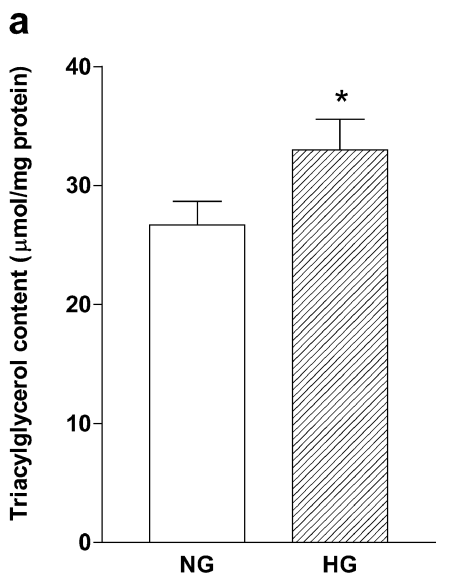

Fig. 8. Bar graphs to show (a) myotubular triacylglycerol (TAG) content, (b) incorporation of 1,2-di[1-14C]oleoylglycerol into TAG and (c) acyl-CoA:1,2-diacylglycerol acyltransferase (DGAT-1) mRNA expression in normoglycaemic (NG) and hyperglycaemic (HG, $20 \mathrm{mmol} / \mathrm{l}$ glucose for 4 days) cells. b

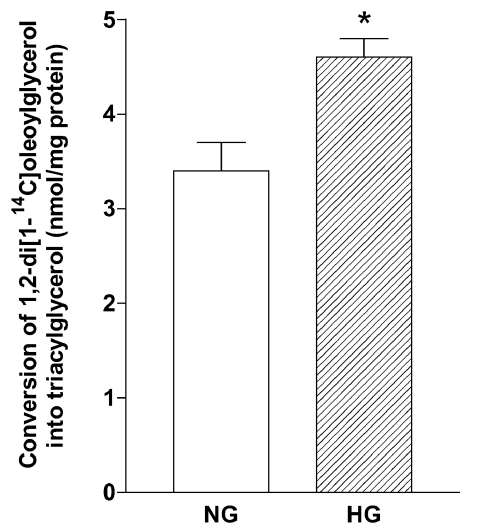

C

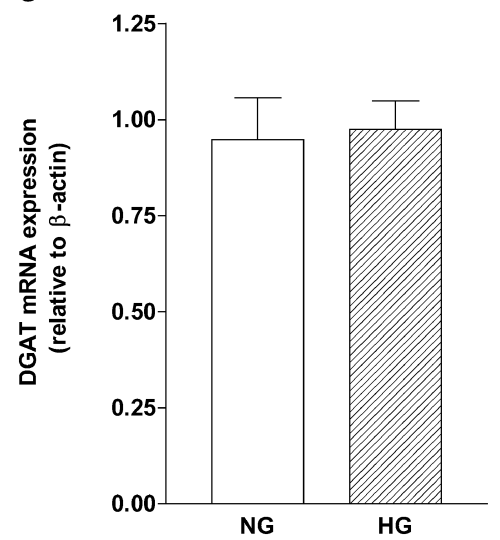

Expression of DGAT-1 mRNA was analysed by real-time RTPCR. Values are means \pm SEM of eight (a), two (b) and five (c) independent experiments. *Significantly higher than NG cells $(p<0.05)$

Table 2. Distribution of $\left[{ }^{14} \mathrm{C}\right]$ palmitic acid in myotubes under normoglycaemic and hyperglycaemic conditions

\begin{tabular}{|c|c|c|c|c|c|c|c|}
\hline & NEFA & DAG & TAG & $\mathrm{CE}$ & PL & Total lipids & ASM \\
\hline Normoglycaemia $(n=4)$ & $13.8 \pm 1.4$ & $8.1 \pm 0.4$ & $70.3 \pm 5.5$ & $5.1 \pm 0.8$ & $37.7 \pm 2.0$ & $135.0 \pm 6.1$ & $13.9 \pm 1.6$ \\
\hline Hyperglycaemia $(n=4)$ & $11.0 \pm 1.5$ & $8.0 \pm 0.9$ & $57.9 \pm 4.1$ & $2.9 \pm 0.5$ & $31.6 \pm 2.3$ & $111.4 \pm 4.7$ & $11.4 \pm 1.0$ \\
\hline
\end{tabular}

Values in $\mathrm{nmol} / \mathrm{mg}$ protein are means $( \pm$ SEM). Control myotubes (treated with normoglycaemic medium containing $5.5 \mathrm{mmol} / \mathrm{l}$ glucose) and myotubes treated with hyperglycaemic medium (20 mmol/l glucose) for 4 days were incubated with $\left[{ }^{14} \mathrm{C}\right]$ palmitic acid $(18.5 \mathrm{kBq} / \mathrm{ml}, 0.6 \mathrm{mmol} / \mathrm{l})$ and $100 \mathrm{nmol} / \mathrm{l}$ insulin for $4 \mathrm{~h}$ before lipids were extracted and sep- arated by thin-layer chromatography. Total cellular uptake of $\left[{ }^{14} \mathrm{C}\right]$ palmitic acid was $148.9 \pm 7.0 \mathrm{nmol} / \mathrm{mg}$ protein in control cells and $122.8 \pm 5.4 \mathrm{nmol} / \mathrm{mg}$ protein in hyperglycaemic cells. ASM, acid-soluble metabolites; CE, cholesterol ester; DAG, diacylglycerol; PL, phospholipids; TAG, triacylglycerol

Table 3. Distribution of $\left[{ }^{14} \mathrm{C}\right]$ oleic acid in myotubes under normoglycaemic and hyperglycaemic conditions

\begin{tabular}{|c|c|c|c|c|c|c|c|}
\hline & NEFA & DAG & TAG & $\mathrm{CE}$ & PL & Total lipids & ASM \\
\hline Normoglycaemia $(n=4)$ & $12.3 \pm 1.5$ & $7.2 \pm 0.4$ & $56.5 \pm 4.6$ & $1.0 \pm 0.1$ & $32.7 \pm 1.2$ & $109.9 \pm 6.3$ & $13.6 \pm 1.0$ \\
\hline Hyperglycaemia $(n=4)$ & $12.0 \pm 2.1$ & $7.0 \pm 0.9$ & $54.2 \pm 4.1$ & $0.9 \pm 0.1$ & $35.0 \pm 2.4$ & $109.1 \pm 6.1$ & $14.4 \pm 0.9$ \\
\hline
\end{tabular}

Values in $\mathrm{nmol} / \mathrm{mg}$ protein are means \pm SEM. Procedure as Table 2 , but with $\left[{ }^{14} \mathrm{C}\right]$ oleic acid $(18.5 \mathrm{kBq} / \mathrm{ml}, 0.6 \mathrm{mmol} / \mathrm{l})$ instead of $\left[{ }^{14} \mathrm{C}\right]$ palmitic acid. Total cellular uptake of $\left[{ }^{14} \mathrm{C}\right]$ oleic acid was $123.5 \pm 6.4 \mathrm{nmol} / \mathrm{mg}$ protein in control cells and

otubes, total cellular uptake of $\left[{ }^{14} \mathrm{C}\right]$ palmitic acid was significantly reduced in hyperglycaemic myotubes $(122.8 \pm 5.4 \mathrm{nmol} / \mathrm{mg}$ protein vs $148.9 \pm 7.0 \mathrm{nmol} / \mathrm{mg}$ protein, $p=0.007)$. This decreased uptake of palmitic acid was reflected in the reduced incorporation of palmitic acid into all lipid classes except diacylglyerol (Table 2). Calculated as a percentage of the corresponding control values, incorporation into PL was reduced to $84 \pm 5 \% \quad(p=0.006)$, TAG to $83 \pm 3 \%$ $(p=0.0004), \mathrm{CE}$ to $72 \pm 14 \% \quad(p=0.08)$, non-esterified intracellular palmitic acid to $76 \pm 9 \%(p=0.02)$ and total cellular lipids to $83 \pm 3 \%(p<0.0001)$ respectively. The relative distribution of the lipid metabolites of
$123.5 \pm 6.7 \mathrm{nmol} / \mathrm{mg}$ protein in hyperglycaemic cells. ASM, acid-soluble metabolites; CE, cholesterol ester; DAG, diacylglycerol; PL, phospholipids; TAG, triacylglycerol

$\left[{ }^{14} \mathrm{C}\right]$ oleic acid was not altered by hyperglycaemia (Table 3).

Fatty acid oxidation, measured as ASM in the cell culture media of cells incubated with either $\left[{ }^{14} \mathrm{C}\right]$ palmitic acid (Table 2) or $\left[{ }^{14} \mathrm{C}\right]$ oleic acid (Table 3), was not affected by hyperglycaemia. Total fatty acid oxidation (the sum of $\mathrm{CO}_{2}$ and ASM generated from $\left[{ }^{14} \mathrm{C}\right]$ oleic acid) was also unchanged in hyperglycaemic myotubes $(104 \pm 7 \%$ of control; $n=6)$. Acute insulin addition $(100 \mathrm{nmol} / \mathrm{l})$ had no effect on oleic acid oxidation when measured as $\mathrm{CO}_{2}$ generation, ASM concentration or total fatty acid oxidation (data not shown). Approximately $20 \%$ of total oleic acid oxida- 
tion was accounted for by $\mathrm{CO}_{2}$ in both control and hyperglycaemic myotubes.

\section{Discussion}

In this study, chronic exposure of skeletal muscle cells to high glucose concentrations caused the accumulation of TAG and increased DGAT-1 activity. These changes were accompanied by reduced basal and insulin-stimulated glucose uptake and glycogen synthesis. The conversion of labelled glucose into lipids indicates that de novo lipogenesis can take place in skeletal muscle cells, and suggests that the lipid accumulation caused by hyperglycaemia is a result of increased lipogenesis. Surprisingly, the elevated lipid synthesis stimulated by glucose was accompanied by a reduced palmitate uptake, whereas glycogen content and expression of GLUT1 and GLUT4 were unchanged. These data suggest that chronic hyperglycaemia stimulates lipogenesis in myotubes rather than glucose accumulation.

The present study is, to our knowledge, the first to show that hyperglycaemia in itself causes the accumulation of fat in human skeletal muscle. Previous studies have shown that, in rats chronically infused with glucose, muscular TAG content is doubled and insulin sensitivity in muscle is decreased [12]. However, hyperglycaemia and hyperinsulinaemia occur in parallel with metabolic and hormonal changes in vivo, and confounding effects of liver and adipose tissue cannot be excluded. In the present study, chronic incubation with $20 \mathrm{mmol} / \mathrm{l}$ glucose increased myotubular TAG content in the absence of exogenously supplied fatty acids (except for 2\% FCS) and increased the incorporation of glucose into TAG. Increased TAG content in skeletal muscles is correlated with insulin resistance [29], and since the myotubes accumulated TAG in the absence of exogenously supplied fatty acids in the present study, skeletal muscle may itself synthesise at least part of the TAG that accumulates during diabetes. The increased conversion of $\left[{ }^{14} \mathrm{C}\right]$ glucose into NEFA and complex lipids also implies an effect on lipogenesis. De novo lipogenesis is low in skeletal muscle-about $5 \%$ of the $\left[{ }^{14} \mathrm{C}\right]$ glucose incubated with our control cells were recovered as cellular lipids-but the present study shows that lipogenesis is stimulated under certain conditions (i.e. when glucose is the only source of energy supplied). Lipogenesis from $\left[{ }^{14} \mathrm{C}\right] \mathrm{ac}-$ etate in rat myotubes has also recently been reported, and in these studies acute hyperglycaemia $(25 \mathrm{mmol} / \mathrm{l})$ increased the rate of lipogenesis [30]. Interestingly, in the present study, hyperglycaemia increased the activity of DGAT-1, the enzyme that catalyses the final step in TAG synthesis. Studies have recently focused on the role of DGAT-1 in obesity and insulin resistance [31, 32, 33]. Mice lacking DGAT-1 have reduced levels of tissue TAG and increased sensitivity to insulin and leptin. Although TAG formation was increased by DGAT-1 after hyperglycaemia in our human myotubes, DGAT-1 mRNA expression was not increased. Hence, the mechanism by which DGAT-1 activity is increased remains to be elucidated.

Our results indicate that insulin resistance was not induced by hyperglycaemia, since the relative insulin responses on glucose uptake and glycogen synthesis were maintained in hyperglycaemic conditions. Hyperglycaemia has previously been shown to induce insulin resistance in muscle $[1,2,34]$. However, this discrepancy is probably due to differences in the definition of insulin resistance. How this reduced glucose utilisation is mediated by hyperglycaemia has been the subject of debate. The present study supports an effect on lipid accumulation, as has been suggested in studies on glucose-infused rats $[12,13,35]$.

The metabolic changes induced by hyperglycaemia most likely occur upstream of the Kreb's cycle, since glucose oxidation to $\mathrm{CO}_{2}$ was not altered in our experiments. One possible explanation could be that glucose oversupply increases the production of the substrates acetyl-CoA and malonyl-CoA for fatty acid biosynthesis. However, an increase in malonyl CoA would be expected to inhibit CPT-1 and fatty acid oxidation [36, 37]. Hyperglycaemia did not alter the oxidation of oleic acid and palmitic acid. The increase in NEFA from labelled glucose suggests that malonylCoA and long-chain acyl-CoAs may be increased, although possibly not to levels sufficient to inhibit CPT1. Alternatively, there could be multiple pools of malonyl CoA in muscle: a cytosolic pool involved in fatty acid synthesis and a pool localised to mitochondria that are involved in the regulation of fatty acid oxidation. The long-chain acyl-CoAs or other related lipid products formed might activate one or more PKC isozymes, as suggested by Laybutt et al. [13]. In line with this, Houdali et al. [35] reported the activation of several PKC isoforms in the skeletal muscle of glucose-infused rats. PKCs are involved in both insulindependent and insulin-independent glucose uptake, and PKCs are strong candidates for mediating both lipid- and glucose-induced insulin resistance $[8,38]$.

Lipid uptake and oxidation are often regulated in concert. We report here that cellular uptake of palmitic acid was decreased after glucose oversupply, while uptake of oleic acid was not; and fatty acid oxidation was unaffected. These results suggest that fatty acid uptake and oxidation can be regulated separately, as shown in a recent study by Turcotte et al. [39]. In their study, high carbohydrate availability was associated with an increase in palmitate uptake in perfused rat muscle. However, this may be due to the fact that they examined a more acute exposure to a high glucose concentration, where rat muscles were perfused for up to $40 \mathrm{~min}$. The mechanism of reduced uptake of palmitic acid in our myotubes is currently unknown, but is apparently specific. There may be a link between in- 
creased lipogenesis and the uptake and metabolism of exogenously added palmitic acid.

Our data show that it is not glucose oversupply as such that causes glycogen accumulation in myotubes. However, in presence of insulin, total cell glycogen was increased, demonstrating the essential role of insulin in promoting glycogen synthesis. Moreover, our results do not suggest that chronic hyperglycaemia regulates the expression of GLUT1 and GLUT4, but it may affect either the activity or translocation of these glucose transporters. An inhibitory effect of hyperglycaemia on PKB activation in skeletal muscle has previously been reported $[34,40]$. In our single-cell system there were no indications of changes in PKB phosphorylation, neither basal nor insulin-stimulated. Mobilisation of GLUT4 and insulin-stimulated glucose uptake has been shown to be dependent on cytosolic $\mathrm{pH}$ in cardiomyocytes [41], and hyperglycaemia may increase lactate production, as reported by Laybutt et al. [12]. We have preliminary data showing an increase of about $50 \%$ in the lactate concentration in the myotubes after hyperglycaemia (unpublished observations).

In summary, we confirm that hyperglycaemia reduces insulin-stimulated glucose uptake and glycogen synthesis concomitantly with increased lipogenesis and intramyotubular TAG accumulation. The increased lipid storage was not caused by decreased fatty acid oxidation, and may instead be due to increased DGAT-1 activity.

Acknowledgements. This work was funded by The University of Oslo, The Norwegian Research Council, The Norwegian Diabetes Association, Freia Chocolade Fabrik's Medicinske Forskningsfond, the S.G. Sønneland Foundation, and Anne Lise Jelstrups legacy (Norway). We thank R. M.-A. Baltzersen, B. Mohebi and J.T. Stuenæs for excellent technical assistance and C. Røe for help with the muscle biopsy sampling.

\section{References}

1. Richter EA, Hansen BF, Hansen SA (1988) Glucose-induced insulin resistance of skeletal-muscle glucose transport and uptake. Biochem J 252:733-737

2. Hansen BF, Hansen SA, Ploug T, Bak JF, Richter EA (1992) Effects of glucose and insulin on development of impaired insulin action in muscle. Am J Physiol 262:E440-E446

3. Boden G, Ruiz J, Kim CJ, Chen X (1996) Effects of prolonged glucose infusion on insulin secretion, clearance, and action in normal subjects. Am J Physiol 270:E251-E258

4. Kawanaka K, Han DH, Gao J, Nolte LA, Holloszy JO (2001) Development of glucose-induced insulin resistance in muscle requires protein synthesis. J Biol Chem 276:20101-20107

5. Jensen J, Aslesen R, Ivy JL, Brors O (1997) Role of glycogen concentration and epinephrine on glucose uptake in rat epitrochlearis muscle. Am J Physiol Endocrinol Metab 35:E649-E655

6. Kawanaka K, Han DH, Nolte LA, Hansen PA, Nakatani A, Holloszy JO (1999) Decreased insulin-stimulated GLUT-4 translocation in glycogen-supercompensated muscles of exercised rats. Am J Physiol 276:E907-E912
7. Saltiel AR, Kahn CR (2001) Insulin signalling and the regulation of glucose and lipid metabolism. Nature 414:799-806

8. Farese RV (2002) Function and dysfunction of aPKC isoforms for glucose transport in insulin-sensitive and insulinresistant states. Am J Physiol Endocrinol Metab 283:E1-E11

9. Derave W, Hansen BF, Lund S, Kristiansen S, Richter EA (2000) Muscle glycogen content affects insulin-stimulated glucose transport and protein kinase B activity. Am J Physiol Endocrinol Metab 279:E947-E955

10. Dimitrakoudis D, Ramlal T, Rastogi S, Vranic M, Klip A (1992) Glycaemia regulates the glucose transporter number in the plasma membrane of rat skeletal muscle. Biochem J 284:341-348

11. Marette A, Dimitrakoudis D, Shi Q, Rodgers CD, Klip A, Vranic M (1999) Glucose rapidly decreases plasma membrane GLUT4 content in rat skeletal muscle. Endocrine 10:13-18

12. Laybutt DR, Chisholm DJ, Kraegen EW (1997) Specific adaptations in muscle and adipose tissue in response to chronic systemic glucose oversupply in rats. Am J Physiol 273:E1-E9

13. Laybutt DR, SchmitzPeiffer C, Saha AK, Ruderman NB, Biden TJ, Kraegen EW (1999) Muscle lipid accumulation and protein kinase $\mathrm{C}$ activation in the insulin-resistant chronically glucose-infused rat. Am J Physiol Endocrinol Metab 277:E1070-E1076

14. Pan DA, Lillioja S, Kriketos AD et al. (1997) Skeletal muscle triglyceride levels are inversely related to insulin action. Diabetes 46:983-988

15. Saha AK, Vavvas D, Kurowski TG et al. (1997) MalonylCoA regulation in skeletal muscle: its link to cell citrate and the glucose-fatty acid cycle. Am J Physiol 272:E641-E648

16. Randle PJ (1998) Regulatory interactions between lipids and carbohydrates: the glucose fatty acid cycle after 35 years. Diabetes Metab Rev 14:263-283

17. Pillay TS, Xiao S, Olefsky JM (1996) Glucose-induced phosphorylation of the insulin receptor. Functional effects and characterization of phosphorylation sites. J Clin Invest 97:613-620

18. Berti L, Mosthaf L, Kroder G et al. (1994) Glucose-induced translocation of protein kinase $\mathrm{C}$ isoforms in rat-1 fibroblasts is paralleled by inhibition of the insulin receptor tyrosine kinase. J Biol Chem 269:3381-3386

19. Muller HK, Kellerer M, Ermel B et al. (1991) Prevention by protein kinase $\mathrm{C}$ inhibitors of glucose-induced insulinreceptor tyrosine kinase resistance in rat fat cells. Diabetes 40:1440-1448

20. Kroder G, Bossenmaier B, Kellerer M et al. (1996) Tumor necrosis factor-alpha- and hyperglycemia-induced insulin resistance. Evidence for different mechanisms and different effects on insulin signaling. J Clin Invest 97:1471-1477

21. Henry RR, Abrams L, Nikoulina S, Ciaraldi TP (1995) Insulin action and glucose metabolism in nondiabetic control and NIDDM subjects-comparison using human skeletal muscle cell-cultures. Diabetes 44:936-946

22. Gaster M, Beck-Nielsen H, Schroder HD (2001) Proliferation conditions for human satellite cells. The fractional content of satellite cells. APMIS 109:726-734

23. Bradford MM (1976) A rapid and sensitive method for quantitation of microgram quantities of protein utilizing the principle of protein-dye binding. Anal Biochem 72: 248-254

24. Franch J, Aslesen R, Jensen J (1999) Regulation of glycogen synthesis in rat skeletal muscle after glycogen-depleting contractile activity: effects of adrenaline on glycogen synthesis and activation of glycogen synthase and glycogen phosphorylase. Biochem J 344:231-235 
25. Aslesen R, Engebretsen EM, Franch J, Jensen J (2001) Glucose uptake and metabolic stress in rat muscles stimulated electrically with different protocols. J Appl Physiol 91:1237-1244

26. Lowry OH, Passonneau JV (1972) A flexible system of enzymatic analysis. Academic Press, New York

27. Folch J, Lees M, Stanley GHS (1957) A simple method for the isolation and purification of total lipids from animal tissues. J Biol Chem 226:497-509

28. Gedde-Dahl A, Bakillah A, Hussain MM, Rustan AC (1999) Tetradecylthioacetic acid (a 3-thia fatty acid) impairs secretion of oleic acid-induced triacylglycerol-rich lipoproteins in $\mathrm{CaCo}-2$ cells. Biochim Biophys Acta 1438:73-84

29. Kelley DE, Goodpaster BH, Storlien L (2002) Muscle triglyceride and insulin resistance. Annu Rev Nutr 22:325-346

30. Guillet-Deniau I, Kone A, Nieruchalski M, Esnous C, Girard J, Prip-Buus C (2003) Glucose induces de novo fatty acid synthesis in rat skeletal muscle through a SREBP-1c dependent pathway. Diabetologia 46 [Suppl 2]:A21 (Abstract)

31. Chen HC, Farese RV Jr (2000) DGAT and triglyceride synthesis: a new target for obesity treatment? Trends Cardiovasc Med 10:188-192

32. Smith SJ, Cases S, Jensen DR et al. (2000) Obesity resistance and multiple mechanisms of triglyceride synthesis in mice lacking DGAT. Nat Genet 25:87-90

33. Chen HC, Smith SJ, Ladha Z et al. (2002) Increased insulin and leptin sensitivity in mice lacking acyl CoA:diacylglycerol acyltransferase 1. J Clin Invest 109:1049-1055

34. Kurowski TG, Lin YS, Luo ZJ et al. (1999) Hyperglycemia inhibits insulin activation of Akt protein kinase B but not phosphatidylinositol 3-kinase in rat skeletal muscle. Diabetes 48:658-663
35. Houdali B, Nguyen V, Ammon HP et al. (2002) Prolonged glucose infusion into conscious rats inhibits early steps in insulin signalling and induces translocation of GLUT4 and protein kinase $C$ in skeletal muscle. Diabetologia 45:356-368

36. Ruderman NB, Saha AK, Vavvas D, Witters LA (1999) Malonyl-CoA, fuel sensing, and insulin resistance. Am J Physiol 276:E1-E18

37. Rasmussen BB, Holmback UC, Volpi E, Morio-Liondore B, Paddon-Jones D, Wolfe RR (2002) Malonyl coenzyme $\mathrm{A}$ and the regulation of functional carnitine palmitoyltransferase- 1 activity and fat oxidation in human skeletal muscle. J Clin Invest 110:1687-1693

38. Matthaei S, Stumvoll M, Kellerer M, Haring HU (2000) Pathophysiology and pharmacological treatment of insulin resistance. Endocr Rev 21:585-618

39. Turcotte LP, Swenberger JR, Yee AJ (2002) High carbohydrate availability increases LCFA uptake and decreases LCFA oxidation in perfused muscle. Am J Physiol Endocrinol Metab 282:E177-E183

40. Oku A, Nawano M, Ueta K, et al. (2001) Inhibitory effect of hyperglycemia on insulin-induced Akt/protein kinase B activation in skeletal muscle. Am J Physiol Endocrinol Metab 280:E816-E824

41. Yang J, Gillingham AK, Hodel A, Koumanov F, Woodward B, Holman GD (2002) Insulin-stimulated cytosol alkalinization facilitates optimal activation of glucose transport in cardiomyocytes. Am J Physiol Endocrinol Metab 283: E1299-E1307 